DOI: https://doi.org/10.31933/jimt.v2i5

Received: 13 April 2021, Revised: 25 Mei 2021, Publish: 17 Juni 2021

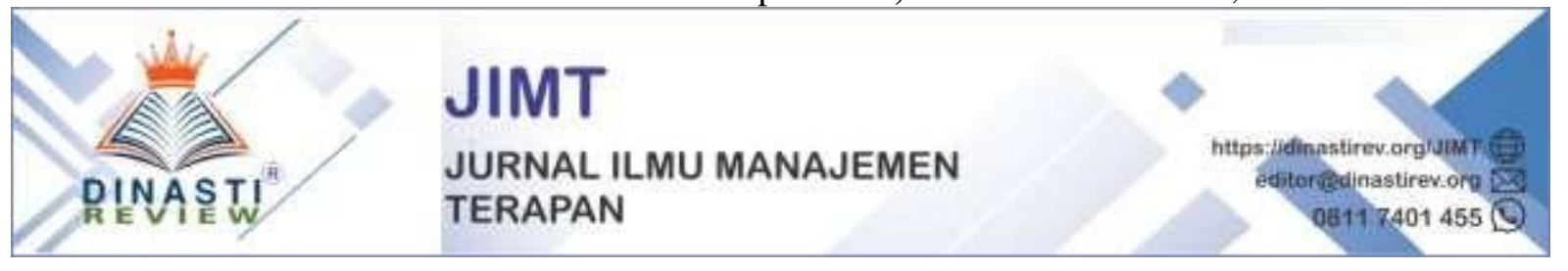

\title{
PENGELOLAAN KEUANGAN DALAM MEMPERTAHANKAN KUALITAS PONDOK PESANTREN SELAMA PANDEMI COVID-19
}

\section{Masruri ${ }^{1}$, Hapzi Ali ${ }^{2}$, Kemas Imron Rosadi ${ }^{3}$}

1) Mahasiswa Program Doktor Manajemen Pendidikan Islam, Universitas Islam Negeri Sultan Thaha Saifuddin Jambi, email: masrurimuhammad81@gmail.com

2) Dosen Pasca Sarjana, Universitas Islam Negeri Sultan Thaha Saifuddin Jambi, email: kemasimronrosadi@uinjambi.ac.id

3) Dosen Pasca Sarjana, Universitas Islam Negeri Sultan Thaha Saifuddin Jambi, email: prof.hapzi@gmail.com

Abstrak: Riset terdahulu atau riset yang relevan sangat penting dalam suatu riset atau artikel ilmiah. Riset terdahulu atau riset yang relevan berfungsi untuk memperkuat teori dan Pengelolaan keuangan dan peningkatan kualitas lembaga-lemabag pendidikan Islam. Artikel ini mereview proses meningkatkan kualitas lemabaga-lembaga pendidikan adalah terletak pada pembiayaan, yaitu: pengelolaan keuagan, kualitas pendidikan, dan sistem informasi keuangan, suatu studi literatur Pengelolaan Keuangan. Hasil artikel literature review ini adalah: 1) Pengelolaan Keuangan untuk meninkatkan kuaitas lembaga-lembaga pendidikan; 2) Teori-teori tentang peningkatan kualitas/mutu lembaga-lembaga pendidikan; dan 3) dampak-dampak dari adaya covid-19 dalam pembiayaan peningkatan kualitas pendidikan.

Kata Kunci: Pengelolaan Keuangan, kualitas Pondok Pesantren, Pandemi Covid 19.

\section{PENDAHULUAN}

\section{Latar Belakang Masalah.}

Permasalahan yang sering menghantui lembaga-lembaga pendidikan, yang terpenting pada lembaga pendidikan Islam di bangsa hari ini, yaitu kesetaraan dalam semua tingkat pendidikan dan berkaitan dengan pembiayaan pendidikan yang dikatakan masih belum maksimal dalam kenyataannya. Pembiayaan dalam bidang pendidikan merupakan bagian terpenting dalam setiap kompenen pendidikan. Pembiayaan dalam setiap pendidikan 
merupakan salah satu masukan atau kritikan yang sangat penting untuk peningkatan penyelenggaraan pendidikan di sekolah atau madrasah

Pendidikan adalah sarana investasi yang akan menjadikan manusia yang memiliki pengetahuan, sikap dan ketrampilan yang dibutuhkan untuk pembangunan bangsa. Manfaat dalam individu, untuk sosial atau institusional segera didapat secara bermacam-macam. Sedangkan manfaat individual tidak akan didapat dalam setiap waktu secara langsung atau diperoleh secara cepat (quick yielding), akan tetapi perlu waktu yang cukup lama dan penuh dengan kesabaran, bahkan bisa satu generasi. Dunia Pendidikan dipandang sebagai sentral utama yang dapat melayani manusia dengan bervariasi pembelajaran, bimbingan dan pelatihan yang diperlukan bagi peserta didik. Pengelolaan keuangan pada setiap lembaga pendidikan berbeda dengan pengelolaan keuangan perusahaan yang memiliki pandangan profit atau laba, memberikan keuntugan atau memberikan kerugian

Pondok Pesantren juga sebagai bagian dari lembaga yang ikut serta dalam memajukan kualitan pendidikan di Indonesia, yang saat ini Pondok Pesantren ikut prihatih, karena setiap anggaran pembiayaan yang telah direncanakan untuk meningkatkan kualitas pendidikan telah dikurangi, dan tidak sesuai dengan harapan dan kebutuhan. Kenapa hal ini, karena di masa pendemi ini anggaran untuk pendidikan dialihkan ke permasalahan di luar pendidikan, melainkan diarahkan ke bantuan-bantuan yang bersifat sosial dan masyarakat.

Akibat dari kebijakan-kebijakan tersebut, Pondok Pesantren sebagai lembaga pendidikan yang berdiri sendiri harus mampu mempertahankan kualitas pendidik, tenaga kependidikan, santri dan seluruh elemen yang ada di dalam Pondok Pesantren.

Dalam upaya mempertahan kualitas mutu pendidikan agar tetap berkualitas, maka perlu adanya pengelolaan secara menyeluruh dan profesional terhadap sumber daya yang ada dalam pondok pesantren. Sebahagian sumber daya yang harus dikelola secara baik dan benar dalam lembaga pendidikan adalah berkaitan dengan keuangan. Dalam hal ini keuangan merupakan sumber dana yang sangat diperlukan setiap lembaga pendidikan khususnya pondok pesantren sebagai alat untuk melengkapi perlengkapan berbagai sarana dan prasarana pendidikan di Pondok pesantren.

Artikel ini menganalisis strategi pondok pesantren dalam mengelola keuangan untuk mempertahankan kualitas pendidikan selama pandemik Covid-19.

\section{Rumusan}

1. Bagaimana pengelolaan keuangan pendidikan?

2. Bagaimana kualitas lembaga pendidikan pondok pesantren?

3. Bagaimana dampak pengelolaan keuangan pondok pesantren selama pandemi covid-19

\section{KAJIAN TEORI}

\section{Pengelolaan Keuangan}


Pengelolaan Keuangan keuangan/sekolah tidak bisa lepas dari yang dinamakan dengan manajemen. Pada dasarnya manajemen berasal dari to manage yang berarti mengatur, mengelola atau mengurusi. Manajemen sering didefenisikan sebagai ilmu, kiat dan profesi. Sebagai sebuah disiplin ilmu, manajemen dipandang sebagai suatu bidang pengetahuan yang secara sistematis berusaha memahami mengapa dan bagaimana sebuah organisasi bekerja sama untuk mencapai tujuan dan membuat sistem kerjasama yang lebih bermanfaat bagi kemanusiaan.

Manajemen pendidikan adalah aktifitas memadukan sumber-sumber pendidikan agar terpusat dalam usaha mencapai tujuan pendidikan yang telah ditentukan sebelumnya. Dan semua manajemen dalam tiap-tiap bagian tersebut haruslah diatur sebaik-baiknya dan mungkin agar tujuan pendidikan dapat tercapai. Namun fenomena yang terjadi sekarang ini ialah kurangnya perhatian manajer/pimpinan mengenai pengelolaan keuangan yang ada di lembaga-lembaga pendidikan. Pengelolaan keuangan merupakan sebuah substansi manajemen lembaga pendidikan/sekolah. Sebagaimana yang terjadi di substansi manajemen keuangan dilakukan melalui proses perencanaan, pengorganisasian, pengarahan, pengkoordinasian pengawasan dan pengendalian. Beberapa kegiatan pengelolaan keuangan yakni yang telah memperoleh dan menentukan sumbersumber pendanaan pemanfaatan dana, pelaporan, pemeriksaaan dan pertanggungjawaban.

Menurut (Brigham and Houston 2019) dalam bukunya berjudul "Fundamental of Financial Management". Menjelaskan tentang Keuangan adalah didefinisikan dalam kamus webster sebagai "sistem yang mencakup peredaran uang, pemberian kredit, melakukan investasi, dan penyediaan fasilitas perbankan". Pembahasan ini akan memberikan gambaran tentang profesional yang berkaitan dengan keuangan dan apa yang mungkin Anda lakukan jika anda termasuk dalam bidang keuangan secara lulus"

Manajemen keuangan, juga disebut keuangan perusahaan, berfokus pada keputusan yang berkaitan dengan berapa banyak dan jenis aset apa yang akan diperoleh, bagaimana cara meningkatkan modal yang dibutuhkan untuk membeli aset, dan bagaimana menjalankan perusahaan untuk memaksimalkan nilainya.

Secara teori yang berkaitan Finance Within an Organization, bagan struktur gambar yang menjelaskan tentang proses struktur dewan dalam pengelolaan keuangan dalam organisasi.

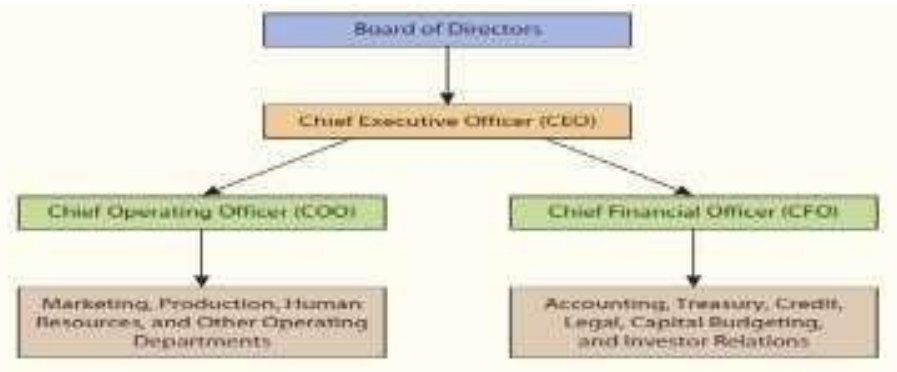

Pada gambar di atas menjelaskan susunan dimulai dari dewan redaksi, pejabat tertinggi eksklusif, kepala operasional, dan kepala bagian keuangan 
Kajian teori di atas juga sudah banyak diteliti oleh peneliti sebelumnya diantaranya adalah: (Al-Adwani and Nabi 1998), (Aina and Bipath 2020)

\section{Kualitas/Mutu}

Menurut Abdul Hadis dan Nurhayati mutu/kualitas ialah hal yang esensial sebagai bagian dalam proses pendidikan. Proses pembelajaran adalah tujuan organisasi pendidikan. Mutu pendidikan adalah mutu lulusan dan pelayanan yang memuaskan pihak terkait pendidikan. Mutu lulusan berkaitan dengan lulusan dengan nilai yang baik (koknitif, apektif, dan psikomotori) diterima melanjutkan ke jenjang yang lebih tinggi yang berkualitas dan memiliki kepribadian yang baik (Peningkatan et al. 2017).

Secara umum mutu pendidikan mengandung makna derajat (tingkat) keunggulan suatu produk (hasil kerja/upaya) baik berupa barang maupun jasa. Dalam konteks pendidikan, pengertian mutu mengacu pada proses pendidikan dan hasil pendidikan. Dalam proses pendidikan yang bermutu terlibat berbagai input, seperti : bahan ajar (kognitif, psikomotorik, afektif), metodologi yang bervariatif sesuai dengan kemampuan guru, sarana dan prasarana sekolah, dukungan administrasi, sumber daya dan dukungan lingkungan yang kondusif

Menurut (Deming, n.d.), mutu adalah perasaaan menghargai bahwa sesuatu lebih baik dari pada yang lain. Perasaan itu berubah sepanjang waktu dan berubah dari generasi ke generasi, serta bervariasi dengan aspek aktivitas manusia. Defenisi lain, "Mutu" seperti yang biasa digunakan dalam manajemen berarti lebih dari rata-rata dengan harga yang wajar. Mutu juga berarti menfokuskan pada kemampuan menghasilkan produk dan jasa yang semakin baik dengan harga yang semakin bersaing.

Kemudian defenisi Kualitas merupakan perkembangan dari peningkatan mutu yang dibicarakan oleh Deming. Kualitas sama juga didefenisikan dengan Totaly Quality Management, yang diperkirakan muncul pada tahun 1980 dari Jepang yang menerapkan peningkatan kualitas secara terus-menerus. Hal ini terus berkembang dan pada tahun 1990 telah banyak diadaptasi oleh banyak perusahaan.

Difenisi Kualitas berkaitan dengan Total Quality Manageent, yang dapat dipahami bahwa TQM merupakan komitmen yang penuh sesungguhnya untuk memuaskan pelanggan melalui penciptaan produk berupa barang atau jasa yang berkualitas. Maka berkaitan dengan kebijakankebijakan seperti pandemi covid, maka teori TQM berorientasi jangka panjang dan dalam implementasinya menggunkan seperangkat alat seperti perencanaan kualitas, dan pengendalian kualitas.(Imron Rosadi Jln Jambi Luar Kota and IAIN Sultan Taha Saefudin 2012)

Filosofi dari kualitas total adalah selalu meningkatkan kualitas barang dan jasa untuk meningkatkan kepuasan pelanggan sebagai strategi jangka panjang perusahaan dalam bersaing dan bertumbuh. Peningkatan kualitas harus dikerjakan seluruh lini perusahaan mulai dari pembelian barang baku, proses produksi, bagian keuangan, bagian sumber daya manusia dan lain-lain

Mendefinisikan mutu/kualitas memerlukan pandangan yang komprehensif. Ada beberapa elemen bahwa sesuatu dikatakan berkualitas, yakni :

1. Kualitas meliputi usaha memenuhi atau melebihi harapan pelanggan.

2. Kualitas mencakup produk, jasa, manusia, proses, dan lingkungan. 
3. Kualitas merupakan kondisi yang selalu berubah (apa yang dianggap berkualitas saat ini mungkin dianggap kurang berkualitas pada saat yang lain).

4. Kualitas merupakan suatu kondisi dinamis yang berhubungan dengan produk, jasa, manusia, proses, dan lingkungan yang memenuhi atau melebihi harapan.

Menurut (Nasution:2004), dalam penerapan TQM, Unsur utama yang dikembangkan oleh (Goetsch dan Davis : 1994) adalah Obsesi terhadap kualitas, yaitu dengan adanya kualitas yang telah ditetapkan, organisasi harus terobsesi untuk memenuhi apa yang telah ditentukan sebelumnya. Artinya adalah bahwa seluruh karyawan setiap level berusaha melaksanakan setiap bagian pekerjaannya yang berdasarkan perspektif untuk melakukan segala sesuatunya dengan benar dan lebih baik.

Dalam bukunya yang berjudul Manjemen Mutu Terpadu oleh Hensler dan Brunnell (dalam Scheuing dan Christopher, 1993: 165-166) yang dikutip oleh Drs. M.N. Nasution, M.S.c., A.P.U., mengatakan bahwa kualitas total merupakan suatu konsep yang berupaya, melaksanakan sistem manajemen kualitas kelas dunia. Untuk itu, diperlukan perubahan besar dalam budaya dan sistem nilai suatu organisasi. Terdapat empat prinsip utama dalam kualitas total, yaitu : 1) Kepuasan pelanggan, 2) Respek terhadap setiap orang, 3) Manajemen berdasarkan fakta, dan 4) Perbaikan berkesinambungan.

J. M. Juran W. E. Deming, (1995) dalam J. L. Ashford, (2003, hlm.5) bahwa praktekpraktek pengelolaan sekolah yang membawa pesan baru sebagai berikut: 1) Manajemen kualitas sangat penting untuk kelangsungan hidup organisasi dan komitmen dari manajemen puncak; 2) Tanggung jawab utama untuk kualitas sesuai dengan pekerjaan yang mereka lakukan. Pengendalian dengan inspeksi merupakan yang nilai terbatas; 3) Untuk tanggung jawab untuk kualitas terletak pada lembaga penjaminan mutu. Manajemen membuat sistem kontrol dan verifikasi dalam pekerjaan, dan mendidik dan mengindoktrinasi tenaga kerja dalam mengaplikasikan pekerjaannya; dan 4) Biaya pendidikan dan pelatihan untuk kualitas, dan biaya lain yang ditimbulkan oleh output (produk gagal sedikit) maka kualitas produk yang lebih baik dan keuntungan yang lebih tinggi.

Kajian teori di atas juga sudah banyak di teliti oleh peneliti lainnya diantaranya adalah: (Mundiri 2017), (Mehtap SÜT and Öznaçar 2017)(Gumus, n.d.), (Mehtap SÜT and Öznaçar 2017), (Aina and Bipath 2020), (Jimenez 2020), (Shahmohammadi 2017)

\section{Lembaga Pendidikan Islam Pondok Pesantren}

Manurut (Ramayulis 2011), Dalam bahasa inggris, lembaga disebut institute (dalam pengertian fisik), yaitu sarana atau organisasi untuk mencapai tujuan tertentu, dan lembaga dalam pengertian non-fisik atau abstrak disebut institution, yaitu suatu sistem norma untuk memenuhi kebutuhan. Lembaga dalam pengertian fisik disebut juga dengan bangunan, dan lembaga dalam pengertian nonfisik disebut dengan pranata. 
Secara terminologi, Amir Daiem mendefinisikan lembaga pendidikan dengan orang atau badan yang secara wajar mempunyai tanggung jawab terhadap pendidikan. Rumusan definisi yang dikemukakan Amir Daiem ini memberikan penekanan pada sikap tanggung jawab seseorang terhadap peserta didik, sehingga dalam realisasinya merupakan suatu keharusan yang wajar bukan merupakan keterpaksaan. Definisi lain tentang lembaga pendidikan adalah suatu bentuk organisasi yang tersusun relatif tetap atas pola-pola tingkah laku, peranan-peranan relasi-relasi yang terarah dalam mengikat individu yang mempunyai otoritas formal dan sangsi hukum, guna tercapainya kebutuhan-kebutuhan sosial dasar (Abdul Munir Mulkhan, 2004 : 103).

Lembaga pendidikan Islam adalah lembaga atau tempat berlangsungnya proses pendidikan yang dilakukan dengan tujuan untuk mengubah tingkah laku individu ke arah yang lebih baik melalui interaksi dengan lingkungan sekitarnya. Perubahan dimaksud tentunya dilandasi oleh nilai-nilai islami. (Munir Toto Suharto, 2011).

Dalam perkembangannya, lembaga pendidikan dapar dibedakan menjadi 3 lembaga, yaitu: Langgar, Pondok Pesantren dan Madrasah

Langgar, atau Surau di Sumatera, selain merupakan tempat mengenalkan dadsar-dasar dan jiwa keagamaan. Pengajarannya Al Quran, do'a dan bacaan sholat bagi anak-anak yang dilakukan dengan cara meniru, mengulang, dan menghapal. Tujuan yang utama agar murid dapat membaca Al Quran sampai khatam.

Pondok Pesantren,Perkataan pesantren berasal dari kata "santri", dengan awalan "pe" dan akhiran "an" yang mempunyai arti asrama tempat santri atau tempat murid belajar mengaji. Pesantren sebagai lembaga pendidikan tradisional Islam untuk mempelajari, memahami, menghayati, dan mengamalkan ajaran Islam dengan menekankan pentingnya moral keagamaan sebagai pedoman perilaku. Pesantren merupakan ciri khas bagi kehidupan para santri untuk mendalami ilmu agama. Ciri utama dari pondok pesantren adalah adanya masjid sebagai pusat kegiatan para santri. Lamanya belajar di pesantren tidak dibatasi, sedangkan materinya hanya pelajaran keagamaan. Yang meliputi: Ushuluddin (pokok-pokok keimanan), Fiqih, Ushul Fiqih, Nahwu, Sharaf, dan sebagainya. Namun, sistem ini lambat laun berkembang sesuai dengan perubahan dan perkembangan zaman. Pesantren mulai mempelajari materi-materi lain, selain materi keagamaan, dengan tanpa mengesampingkan nuansa keagamaannya, tradisi pesantren yang telah ada.(Alwi 2016), 
Kajian teori tentang pesantren sudah banyak dikaji oleh peneliti lainnya, diantaranya adalah: (Junaidi 2017), (Siregar 2018), ("Manajemen Pendidikan Untuk Pondok Pesantren | MANAGERIA: Jurnal Manajemen Pendidikan Islam” n.d.)

\section{Pandemi Covid 2019}

Pandemi berasal dari bahasa Yunani, yaitu dari kata pan yang artinya semua dan kata demos yang berarti rakyat. Jadi arti pandemi secara istilah ialah penyakit menular yang bisanya menyebar luas ke beberapa benua atau seluruh dunia dan memengaruhi orang dalam skala besar (skala internasional).

Corona telah berdampak pada pendidikan dunia, sekitar 300 juta pelajar kegiatan sekolahnya terganggu dan terancam masa depan pendidikannya. Begitu juga di Indonesia, sektor pendidikan pun ikut merasakan dampaknya. Jika pandemi terus meningkat, maka akan dipastikan dampak pada sektor pendidikan juga akan meningkat. Yang lebih dikhawatirkan adalah efek jangka panjang. Jika pandemi covid-19 ini tidak segera berakhir, maka otomatis para pelajar akan merasakan hambatan sehingga terjadi keterlambatan dalam menjalani proses yang sedang dijalaninya. Juga kebijakan negara-negara yang berpotensi tersebarnya virus untuk penundaan sekolah-sekolah di negara pastinya akan mengacaukan hak-hak warga negaranya dalam mendapatkan pendidikan yang baik

Berikut Teori-teori dibahas sudah banyak diteliti oleh peneliti lannya, dianataranya : (“MENUMBUHKAN KEMANDIRIAN SISWA SELAMA PEMBELAJARAN DARING SEBAGAI DAMPAK COVID-19 DI SD | Kusumadewi | Jurnal Riset Pendidikan Dasar (JRPD)" n.d.), (Jurnal et al. 2020), (Preventif Pemimpin Dalam Pencegahan Penyebaran COVID- et al., n.d.)

Berikut ini adalah paparan apa saja faktor-faktor penyebab terhambatnya pendidikan bagi rakyat kecil yang tidak merasakan segala kemudahan sehingga menjadi dampak yang negatif bagi pendidikan di tengah wabah corona ini, yaitu:

a) Penguasaan teknologi yang masih rendah

b) Terbatasnya Sarana dan Prasarana

c) Minimnya jaringan internet

d) Pengurangan pembiayaan

Kajian teori di atas juga sudah banyak di teliti oleh peneliti sebelumnya diantaranya adalah: (Mehtap SÜT and Öznaçar 2017), (Mehtap SÜT and Öznaçar 2017), (Jimenez 2020). 
Berdasarkan teori-teori yang telah dikemukakan tersebut di atas, akhirnya penulis menyimpulkan bahwa pengelolaan keuangan memiliki pengaruh dan dampak bagi lembaga pendidikan dalam meningkatkan kualitas lembaga-lembaga pendidikan, seperti peningkatan kualitas kegiatan belajara mengajar di saat pandemi, lembaga dituntut untuk meningkatkan kualitas peserta didik, tanpa harus tatap muka, dan tanpa kontak fisik, dimasa pandemi ini pendidik dalam sebuah lembaga pendidikan harus tetap mendidik dan mengajar. Oleh karena itu, lembaga pendidikan sebagai dewan redaksi dan pejabat tertinggi lembaga bertanggung jawab memberikan dukungan kepada pendidik, tenaga kependidikan, peserta didik, serta sarana dan prasarana yang mendukung setiap program lembaga pendidikan. Kaitannya dengan pengelolaan keuangan lembaga pendidikan untuk meningkatkan kualitas, lembaga pendidikan harus lebih mengutamakan ke sektor proses pembelajaran melalu daring yang ditetapkan oleh pemerintah Pusat maupun pemerintah daerah

\begin{tabular}{|c|c|c|c|}
\hline $\begin{array}{c}\text { Rencana } \\
\text { Anggaran } \\
\text { Lembaga }\end{array}$ & Proses Penyaluran & $\begin{array}{c}\text { Delapan } \\
\text { Strandan } \\
\text { Pendidikan } \\
\text { (Guru \& Sarana) }\end{array}$ & Peningkatan \\
Kualiatas \\
Pemabaga \\
Pendidikan
\end{tabular}

\section{Gambar 1: Sektor Pengelolaan keuangan lembaga pendidikan untuk kualitas pendidikan selama pandemi}

\section{METODE PENULISAN}

Metode penulisan artikel ilmiah ini adalah dengan metode kualitatif dan studi literature atau Library Research. Mengkaji Buku-buku literature sesuai dengan teori yang di bahas khusunya di lingkup pengelolaan keuangan dalam meningkatkan kualitas lembaga-lembaga pendidikan Islam. Disamping itu menganalisis artikel-artikel ilmiah yang bereputasi dan juga artikel ilmiah dari jurnal yang belum bereputasi. Semua artikel ilmiah yang di citasi bersumber dari Mendeley dan Scholar Google.

Dalam penelitian kualitatif, tinjauan pustaka memiliki beberapa tujuan utama mengkonfirmasikan kepada pembeca hasiil-hasil penelitian lainyang berkaitan erat dengan penelitian yang akan dilakukan pada saat ini, menghubungkan penelitian dengan litaraturlitertur yang ada, dan mengisi celah-celah dalam penelitian-penelitian sebelumnya.("Research Design Qualitative, Quantitative, and Mixed Methods Approaches by John W. Creswell (zLib.Org).Pdf," n.d.)

Selanjutnya dibahas secara mendalam pada bagian yang berjudul" Pustaka Terkait" (Related Literature) atau Kajian pustaka("Review of Literature"), sebagai dasar perumusan hipotesis dan selanjutnya akan menjadi dasar untuk melakukan perbandingan dengan hasil atau temuan-temuan yang terungkap dalam penelitian, (Ali \& Limakrisna, 2013).

\section{PEMBAHASAN}

Artikel ini menganalis dan membahas tentang pengelolaan keuangan dalam meningkatkan kualitas lembaga pendidikan. Dimana pengelolaan keuangan dalam rangka meningkatkan kualitas pendidikan di setiap lembaga-lembaga pendidikan Islam tetap 
diutamakan pada peningkatan pembiayaan dalam bidang tenaga pendidik dan tenaga kependidikan serta peningkatan pembiayaan sarana dan prasarana selama pendemi, Riset dan artikel terdahulu dan relevan dengan artikel ini di antarnya adalah:

\section{1) Konsep Manajemen/Pengelolaan Keuangan Pendidikan}

Manajemen keuangan pendidikan atau disebut juga dengan pembiayaan pendidikan adalah sejumlah kegiatan yang berhubungan dengan pengadaan keuangan, pemanfaatan keuangan hingga pertanggung jawaban keuangan dengan harapan tercapainya tujuan pendidikan secara efektif dan efisien. (Siagian, 2012).

Menurut Nanang Fattah pembiayaan pendidikan adalah sejumlah uang yang dihasilkan dan dimanfaatkan untuk membiayai kebutuhan pendidikan, seperti gaji guru, pengadaan sarana dan prasarana, peningkatan profesionalitas guru, kegiatan ekstrakurikuler, kegiatan supervisi pendidikan. (Andiawati, n.d.)

Teori ini sejalan dengan penelitian yang dilakukan oleh (Alkurnia and Anggraini 2017), (Lestari 2019), (Andiawati, n.d.), dan yang mengemukakan bahwa pengelolaan keuangan dapat meningkatkan kualitas pendidikan.

Ada beberapa prinsip-prinsip yang menjadi dasar pengelolaan keuangan yaitu, 1) Akuntabilitas adalah : Proses manajemen pembiayaan pendidikan harus mampu mempertanggung jawabkan bagaimana dana itu diperoleh dan digunakan baik kepada diri sendiri, anggota organisasi maupun kepada public, 2) Transparan ; adalah Proses pengelolaan pembiayaan pendidikan harus dilakukan secara trasparan dan mampu di akses oleh pihak yang berkepentingan. Prinsip ini bisa direalisasikan dengan menyusun laporan terhadap pengelolaan dana yang ada. 3) Integeritas, yaitu Pelaksanaan manajemen pembiayaan pendidikan harus memiliki integritas, baik sistem yang dibangun maupun sumber daya manusia yang menjalankannya. 4) Konsitensi, yakni artinya pengelolaan dana pendidikan harus dilakukan secara konsisten dengan tetap memperhatikan dinamika dan perubahan organisasi yang ada. Konsistensi ini juga disesuaikan dengan visi, misi dan tujuan lembaga pendidikan yang telah ditentukan. 5) Efektif dan efesien, yaitu Pengelolaan dana pendidikan harus dilakukan secara efektif dan efisisen dan fokus pada tujuan yang hendak dicapai. Prinsip inilah yang menjadikan indikator produktivitas lembaga pendidikan.

Terkait dengan fungsi manajemen pembiayaan pendidikan, Mulyasa (2006;195) mengatakan bahwa dana (biaya) memainkan peran penting dalam pendidikan pada tiga area; pertama, ekonomi pendidikan dalam kaitannya dengan pengeluaran masyarakat secara keseluruhan. Kedua, keuangan sekolah kaitannya dengan kebijakan sekolah untuk menerjemahkan uang terhadap layanan kepada peserta didik. Ketiga, pajak administrasi bisnis sekolah yang harus diorganisir secara langsung berkaitan dengan tujuan kebijakan. Pusat perhatian mendasar dari konsep ekonomi adalah bagaimana mengalokasikan sumber-sumber terbatas untuk mencapai tujuan yang beraneka ragam mungkin tak terhingga.

\section{2) Kulitas Lembaga Pendidikan Pondok Pesantren}

Kualitas lembaga-lembaga pendidikan Islam adalah lembaga yang mengutamakan pembiayaannya untuk peningkatan lembaga seperti tenaga pendidik, tenaga kependidikan, sarana dan prasarana.

Biaya pendidikan merupakan salah satu komponen instrumental yang sangat penting dalam penyelenggaan pendidikan. Tidak ada kegiatan pendidikan yang dapat mengabaikan peranan biaya, karena tanpa biaya maka proses pendidikan tidak dapat berjalan secara optimal. 
Pembiayaan pendidikan merupakan salah satu bahan kajian yang penting untuk meningkatkan kualitas lembaga pendidikan. Pembiayaan lembaga pendidikan mencakup pengelolaan dana lembaga pendidikan yang sesuai dengan standar pembiayaan yaitu peraturan Menteri pendidikan Nasional Noor 69 tahun 2009 yang menyebutkan, yakni 1) anggaran sekolah dirumuskan merujuk peraturan pemerintah pusat dan daerah, 2) pengelolaan keuangan sekolah transfaran, efisien, dan akuntabel, dan 3) sekolah membuat pelaporan keuangan kepada pemerintah dan pemangku kepentingan (Ufifatul Ilma : 2015)

Keterkaitan antara pembiayaan (keuangan) dengan kualitas jelas saling terikat. Dalam pelaksnaannya, pembiayaan harus didasarkan pada tingkat kualitas tertentu. Banyak faktor yang bisa dilakukan untuk meningkatkan kualitas lembaga pendidikan. Pembiayaan atau keuangan bukan salah satu jawaban yang harus dipenuhi penyelenggaraan pendidikan. Dalam hal ini perlu diupayakan syarat oleh para pengelola pendidikan untuk menunjukkan langka efesiensi yang dilakukan serta akuntabilitas dalam pengelolaan keuangan. Sebeb tanpa didukung dengan langkah efesiensi dan akuntabilatas dalam pengelolaan dana. Berapapun dana yang dikeluarkan, aktivitas yang dilakukan lembaga tidak akan berhasil meningkatkan kualitas pendidikan. Oleh karena itu, pengelolaan pendidikan dituntut nelakukan efesiensi dan akuntabilas (Indra Bastian : 2006).

Artinya pengelolaan keuangan pendidikan dengan kualitas lembaga pendidikan saling terkait dalam penyelenggaraan pendidikan. Sebab tanpa didukung langkah efesiensi dan akuntabilitas dalam pengelolaan dana, berapapun dana yang dikeluarkan, aktivitas yang dilakukan lembaga tidak akan berhasil meningkatkan kualitas pendidikan. Sedangkan untuk mewujudkan pendidikan yang berkualitas, perlu adanya pengelolaan secara menyeluruh dan profesional terhadap sumber daya yang ada dalam lembaga pendidikan. Implikasi pengelolaan keuangan dalam meningkatkan kualitas pendidikan yaitu dengan adanya pengalokasian dana pada faktor-faktor yang mempengaruhi proses pembelajaran yang memerlukan anggaran dalam meningkatkan kualitas pendidikan. Dengan adanya anggaran dana yang dialokasikan untuk pembelajaran diharapkan dapat menunjang semua kegiatan demi penigkatan mutu lembaga pendidikan. Hasil ini mendukung teori ungkapan Tjandra tujuan dari pembiayaan pendidikan diantaranya adalah meningkatkan penggalian sumber biaya lembaga pendidikan dan menciptakan pengendalian yang tepat sumber keuangan organisasi pendidikan (Makmur Syukri : 2020) .

Salah satu bagian terpenting dalam pondok pesantren adalah berkaitan denggan pengelolaan keuanggan pesantren. Pengelolaan keuangan sendiri adalah pengurusan dan pertanggung jawaban suatu lembaga terhadap penyandang dana baik individual maupun lembaga. Dalam penyusunan anggaran memuat pembagian penerimaan dan pengeluaran anggaran rutin dan anggaran pembanggunan serta anggaran incidental jika perlu. Prinsipprinsip pengelolaan pendidikan sebagai berikut:

a) Hemat tidak mewah, efisien, dan sesuai denggan kebutuhan

b) Terarah dan terkendali sesuai dengan rencana dan program

c) Terbuka dan transparan 
d) Sedapat mungkin menggunakan kemampuan/hasil produksi dalam negeri sejauh hal ini di mungkinkan

Pesantren bersama-sama merumuskan rencana anggaran pendapatan dan belanja pesantren (RAPBP) sebagai acuan bagi penggelola pesantren melaksanakan menejemen keuangan yang baik. Adapun sumber pendapatan pondok pesantren dalam satu tahun meliputi: konstribusi santri, sumbanggan dari individu dan organisasi, sumbanggan dari pemerintah bila ada, dari hasil usaha.

Semua penggunaan uang pesantren dalam satu tahun anggaran perlu di rencanakan dengan baik agar kehidupan pesantren dapat berjalan dengan baik. Penggunaan uang pesantren tersebut menyangkut seluruh pengeluaran yang berkaitan denggan kebutuhan penggelolaan pesantren, temasuk dana operasional harian, penggembangan sarana dan prasarana pesantren, infaq semua petugas pesantren, dana kerja sama, dan bahkan dana praktis lain-lainya perlu di rencanakan denggan baik.

Satu hal yang perlu diperhatikan dalam penyusunan rencana anggaran pendapatan dan belanja pesantren adalah menerapkan prinsip anggaran berimbang artinya rencana pendapatan dan pengeluaran harus seimbang diupayakan tidak terjadi anggaran pendapatan minus.

\section{3) Dampak Pengelolaan Keuangan Selama Pandemi Covid -19}

Pada awal kebijakan pemerintah berkaitan dengan munculnya pendemi covid-19, hal ini berdampak pada indeks pasa modal yang mencerminkan merosotnya semua aktivitas tanpa terkecuali termasuk di bidang pendidikan.

Merespon pandemi covid-19, pemerintah Indonesia mulai menerapkan pembatasan dengan kebijakan social distancing (menghidari kerumunan), lalu physical distancing (Jaga jarak antar orang minimal 1,5 meter). Kebijakan ini telah menurunkan secara drastis aktivitas dan pergerakkan orang di manapun di seluruh Indonesia, bahkan Dunia merasakan hal itu.

Pandemi covid-19 sangatlah memberikan dampak yang besar, khususnya di bidang pendidikan khususnya lembaga-lembaga pendidikan. Khususnya berkaitan tentang pengelolaan keuangan pendidikan, sumber-sumber dana yang diperoleh sebelum pandemi lancar dan terkendali, selanjutnya selama pandemi covid-19 sudah mulai tidak terkedali, padahal semua itu sumber untuk peningkatan kualitas dan mutu lembaga pendidikan.

Adapun yang menjadi dampak dari peningkatan kualitas lembaga pendidikan pondok pesantren selama covid-19 adalah 1) kurang lancarnya proses kewajiban orang tua dalam melunasi iuran SPP di lembaga pendidikan pondok pesantren, yang beresiko ketidak seimbangan antara pemasukkan dan pengeluaran, sehinnga terhambatnya pemberian hak kepada pendidik dan terhambatnya peningkatan kualitas pendidikan di lembaga pendidikan. 2) 
Dengan adanya kebijakan pembelajaran daring selama pandemi covid-19, sehingga terhambat pula proses peningkatan sumber daya manusia yang berkualitas, karena proses belajar mengajarnya terganggu oleh signal, paket data internet, kerugian santri pada proses penilaian, berdampaknya pada proses penilaian yang kurang obyektif serta kebutuhan-kebutuhan yang berkaitan dengan pembelajaran daring.

Dari dampak pandemi covid-19 di atas. Menteri pendidikan dan kebudayaan memberikan kelonggaran dalam penggunaan dana operasional untuk kepentingan pembelajaran daring selama pandemi. Diantara kelonggaran yang diberikan adalah untuk pembelian paket data atau layanan pendidikan daring berbayar bagi pendidik dan peserta didik, kemudian dana dapat digunakan untuk pembelian cairan atau sabun pembersih untuk kepentingan sekolah (Pendidikan, Kebudayaan, and Indonesia 2013) .

\section{KESIMPULAN DAN SARAN \\ Kesimpulan}

Berdasarkan pembahasan, maka dapat disimpulkan untuk pengelolan keuangan dalam meningkatkan kualitas lembaga-lembaga pendidikan, selanjutnya seperti di bawah ini:

1) Pelaksanaan pengelolan keuangan dalam sebuah organisasi pendidikan terdapat dewan redaksi, pejabat tertinggi eksklusif, kepala operasional, dan kepala bagian keuangan dan pengelolaan keuangan pendidikan adalah sejumlah kegiatan yang berhubungan dengan pengadaan keuangan, pemanfaatan keuangan hingga pertanggung jawaban keuangan dengan harapan tercapainya tujuan pendidikan secara efektif dan efisien

2) Peningkatan kualitas dalam organisasi, maka diperlukan 1) Manajemen kualitas dengan komitmen untuk kelangsungan hidup organisasi menuju manajemen puncak; 2) bertanggung jawab terhadap kualitas, 3) Harus adanya lembaga penjaminan mutu. dan 4) Adanya pembiayaan pendidikan untuk meningkatkan kualitas

3) Dampak pelaksanaan pengelolaan keuangan pada pondok pesantren selama pandemi covid-19 adalah: kurang lancarnya proses kewajiban orang tua dalam melunasi iuran SPP di lembaga pendidikan pondok pesantren, yang beresiko ketidak seimbangan antara pemasukkan dan pengeluaran dan terhambat pula proses peningkatan sumber daya manusia yang berkualitas, karena proses pembelajaran yang masih perlu bantuan jaringan yang kurang mendukung.

\section{Saran}

Bersdasarkan Kesimpulan di atas, maka saran pada artikel ini adalah bahwa masih banyak usaha dan upaya dalam pengelolaan keuangan dalam rangka mempertahankan kuaitas lembaga pendidikan pondok pesantren, oleh karena itu masih diperlukan kajian yang lebih lanjut untuk melengkapi bagaimana upaya pengelolaan keuangan dalam mempertahankan kualitas lembaga pendidikan pondok pesantren selama pandemi covid-19

\section{Bibliography}

Aina, Adebunmi Yetunde, and Keshni Bipath. 2020. "School Financial Management: Insights for Decision Making in Public Primary Schools." South African Journal of Education 40 
(4). https://doi.org/10.15700/saje.v40n4a1756.

Al-Adwani, Andrew, and Wahid Nabi. 1998. "Financial Management in Patients with Dementia; Their Adult Children's Knowledge and Views." International Journal of Geriatric Psychiatry $13 \quad$ (7): 462-65. https://doi.org/10.1002/(SICI)10991166(199807)13:7<462::AID-GPS797>3.0.CO;2-C.

Ali, H., \& Mappesona, H. (2016). Build brand image: Analysis Service Quality and Product Quality (case study at Giant Citra Raya). International Journal of Economic Research.

Alkurnia, Risa, and Aulia Anggraini. 2017. "PENGELOLAAN MANAJEMEN KEUANGAN PADA LEMBAGA PENDIDIKAN (Studi Pada Sekolah Al-Islam Dan Muhammadiyah Di Surakarta)." Prosiding Seminar Pendidikan Ekonomi Dan Bisnis. Vol. 3. https://jurnal.fkip.uns.ac.id/index.php/snpe/article/view/10710.

Alwi, B. Marjani. 2016. "PONDOK PESANTREN: CIRI KHAS, PERKEMBANGAN, DAN SISTEM PENDIDIKANNYA." Lentera Pendidikan: Jurnal Ilmu Tarbiyah Dan Keguruan 16 (2): 205-19. https://doi.org/10.24252/lp.2013v16n2a8.

Andiawati, Etty. n.d. "PENGELOLAAN KEUANGAN LEMBAGA PENDIDIKAN / SEKOLAH."

Brata, Husani, Hapzi, B. H. S. A. (2017). Saudi Journal of Business and Management Studies Competitive Intelligence and Knowledge Management: An Analysis of the Literature. Saudi Journal of Business and Management Studies. https://doi.org/10.21276/sjbms

Brigham, Eugene F, and Joel F Houston. 2019. Fundamentals of FINANCIAL MANAGEMENT 15e. Cengage Learning.

Deming, Cara. n.d. "Peningkatan Mutu Pendidikan Terpadu Cara Deming," no. 04: 106-12. Gumus, Fatma Nezihe. n.d. "Review of One of the Education Policies: Total Quality Management in Schools." https://doi.org/10.30918/AERJ.8S2.20.052.

Imron Rosadi Jln Jambi Luar Kota, Kemas, and Kampus IAIN Sultan Taha Saefudin. 2012. "Efektifitas Kinerja Lembaga Penjaminan Mutu Pendidikan (LPMP) Dalam Meningkatkan Mutu Pendidikan." Jurnal Administrasi Pendidikan 14 (1): 1-19. https://doi.org/10.17509/jap.v14i1.6703.

Jimenez, Laura. 2020. "Student Assessment During COVID-19."

Junaidi, Kholid. 2017. "Sistem Pendidikan Pondok Pesantren Di Indonesia (Suatu Kajian Sistem Kurikulum Di Pondok Pesantren Lirboyo)." Istawa: Jurnal Pendidikan Islam 2 (1): 95. https://doi.org/10.24269/ijpi.v2i1.364.

Jurnal, Al-Hikmah:, Studi Islam, K H Lalu, Gede Muhammad, and Zainuddin Atsani. 2020. "TRANSFORMASI MEDIA PEMBELAJARAN PADA MASA PANDEMI COVID-19." $\begin{array}{llllll}\text { Al-Hikmah: } \quad \text { Jurnal } & \text { Studi } & \text { Islam } & 1 & \text { (1): }\end{array}$ http://ejournal.kopertais4.or.id/sasambo/index.php/alhikmah/article/view/3905.

Lestari, Meyranti Iloe. 2019. "SISTEM PENGELOLAAN KEUANGAN PROGRAM PENDIDIKAN GRATIS DI PESANTREN." Jurnal Manajemen Dan Supervisi Pendidikan 3 (3): 115-23. https://doi.org/10.17977/um025v3i32019p115.

"Manajemen Pendidikan Untuk Pondok Pesantren | MANAGERIA: Jurnal Manajemen Pendidikan Islam." n.d. Accessed April 14, 2021. http://ejournal.uinsuka.ac.id/tarbiyah/index.php/manageria/article/view/1063.

Mehtap SÜT, Hüsne, and Behçet Öznaçar. 2017. "International Journal of Curriculum and Instruction Effects of COVID-19 Period on Educational Systems and Institutions Conditions of the Creative Commons Attribution License (CC BY-NC-ND)." 
International Journal of Curriculum and Instruction. Vol. 13.

"MENUMBUHKAN KEMANDIRIAN SISWA SELAMA PEMBELAJARAN DARING SEBAGAI DAMPAK COVID-19 DI SD | Kusumadewi | Jurnal Riset Pendidikan Dasar (JRPD)." n.d. Accessed April 2021. http://jurnalnasional.ump.ac.id/index.php/jrpd/article/view/7927/3245.

Mundiri, Akmal. 2017. "Organizational Culture Base On Total Quality Management In Islamic Educational Institution." ADRI International Journal Of Islamic Studies and Social Sciences 1 (1): 1-11.

Pendidikan, Menteri, D A N Kebudayaan, and Republik Indonesia. 2013. "Peraturan Menteri Pendidikan No. 19 Tahun 2020," 2013-15.

Peningkatan, Manajemen, Mutu Pendidikan, Muhammad Fadhli, Kata Kunci, Peningkatan Mutu, and Manajemen Mutu Pendidikan. 2017. "Manajemen Peningkatan Mutu Pendidikan." TADBIR : Jurnal Studi Manajemen Pendidikan 1 (2): 2.

http://journal.iaincurup.ac.id/index.php/JSMPI/article/view/295.

Preventif Pemimpin Dalam Pencegahan Penyebaran COVID-, Peran, Strategi Syaykh AlZaytun Di Ma, had Al-Zaytun dan Kontribusinya Terhadap Masyarakat Sekitar Imam Prawoto, Siti Ngainnur Rohmah, Fitri Rachmiati Sunarya, Optimalisasi Upaya Pemerintah Dalam Mengatasi Pandemi Covid, Sebagai Bentuk Pemenuhan Hak Warga Negara Bima Jati, and Gilang Rizki Aji Putra. n.d. "Dampak Covid-19 Pada Pendidikan Di Indonesia: Sekolah, Keterampilan, Dan Proses Pembelajaran Rizqon Halal Syah Aji Peran Majelis Ulama Indonesia Dalam Mitigasi Pandemi Covid-19; (Tinjauan Tindakan Sosial Dan Dominasi Kekuasaan Max Weber) Muhamad Agus Mushodiq, Ali Imron Pandangan Keagamaan Majelis Ulama Indonesia Kabupaten Bogor Terkait Kewajiban Menjaga Diri, Pelaksa-Naan Shalat Jumat Dan Pengurusan Mayit Dalam Situasi Darurat Penyebaran Covid-19 Ahmad Mukri Aji.” https://doi.org/10.15408/sjsbs.v7i5.15314.

"Research Design Qualitative, Quantitative, and Mixed Methods Approaches by John W. Creswell (z-Lib.Org).Pdf." n.d.

Shahmohammadi, Nayereh. 2017. "The Evaluation of Teachers' Job Performance Based on Total Quality Management (TQM)." International Education Studies 10 (4). https://doi.org/10.5539/ies.v10n4p58.

Siregar, Muammar Kadafi. 2018. "Pondok Pesantren Antara Misi Melahirkan Ulama Dan Tarikan Modernisasi." Jurnal Pendidikan Agama Islam Al-Thariqah 3 (2): 16-27. https://doi.org/10.25299/althariqah.2018.vol3(2).2263. 